British Journal of Education

Vol.8, Issue 2, pp.104-121, February 2020

Published by ECRTD- UK

Print ISSN: ISSN 2054-6351

Online ISSN: ISSN 2054-636X

\title{
A PROPOSED PERCEPTION FOR DEVELOPING A SURVEILLANCE SYSTEM USING THE CAMERAS TECHNOLOGY ON SCHOOLS IN THE KINGDOM OF SAUDI ARABIA
}

\author{
Dr-Mohammad bin Abdullah bin Mohammad Faqih
}

Ministry of education- Kingdom of Saudi Arabia

\begin{abstract}
This study aimed at presenting a proposed perception for developing a surveillance system using the cameras technology on schools in the Kingdom of Saudi Arabia. The population of the study consisted of all male and female school principals, in the Department of Education for Riyadh District. They were (1186) male and female principals. The study sample consisted of (301) male and female principals. They were drawn from the population by using stratified random sample method. The descriptive - survey methodology was used. To achieve the objectives of the study, a questionnaire was developed. It consisted of (16) items to find out the obstacles of applying surveillance system on schools by using cameras technology. The results showed that there were many obstacles facing school principals in accepting the surveillance system on their school administrations using camera technology with a high degree. The technical obstacle came first and human obstacle last. The results also indicated the necessity of adopting legal legislations that allow the use of surveillance cameras in schools, so that there were no violation of the privacy of school employees and visitors, as well as to develop signboards that show the presence of surveillance cameras and choose suitable places in schools to install these cameras based on an engineering and psychological study.
\end{abstract}

KEYWORDS: Surveillance system, Cameras technology, Kingdom of Saudi Arabia.

\section{INTRODUCTION}

Management is currently one of the tools that contemporary societies use for their development and renaissance. Nations have become uneven and vary among themselves in the way they manage, as the administration works to make optimal use of the available resources to achieve the goals of society in an efficient and effective manner. Management, in its public and private sense, interferes in this age in all societies of all kinds.

One of the most prominent terms describing the twenty - first century is the knowledge explosion, the information age, and scientific progress. Today's world is rapidly changing world dominated by information and communications technology, to the point where it has become the main effect and the tool for many of its features. As a result, knowledge increased rapidly. This revolution affected the administration in general and the educational administration in particular. Therefore, the educational administration required to interact with the requirements of the new era by employing modern technologies in operations including oversight. It becomes necessary 
to use modern technologies to develop the administrative system. The current era is characterized by change rapid and continuous development, and it is an era that witnesses a lot of scientific and technological progress in all areas of life. This development must be accompanied by a parallel development in administrative systems and the use of modern scientific and technological methods to manage it effectively, as the progress or backward societies become subject to the development or backward of its administrative system. The developed countries did not reach the advanced level they reached today in all their facilities except through the presence of a modern advanced administration capable of bringing about the desired change (Nyagowa, Ocholla \& Mutual, 2011).

School principals are under pressure to search for ways to enhance student achievement and oversight. One effective way to this is to use technology to enhance instructions, communication and database management for developing administrative practices. School principals are looking for ways to develop and manage their schools effectively (Bell, 2011).

Al - Saidi (2007) believed that the technical and scientific revolution is one of the largest intellectual movements that man invented in his long and fastest civilization march. Therefore, we find that the primary goal of technologies in all its forms is the optimal use of human knowledge and the provision of welfare to humankind. The technology has been able to provide the human being with a lot of information, experiences, means and devices that enabled him to perform his/ her role in developing his society well. As well as increasing productivity. As for Race (2005) he saw that the emergence of the concept of technology in its precise scientific sense in the twentieth century linked a large number of people with modern devices and tools that appeared in the same century with the concept of technology.

Modern technology represents the important element in contemporary life, as it has become necessary for any educational organization to have a set of modern technologies in order to be able to provide you with the information you need that constitute the vital source that enables the organization to be able to make the necessary decisions to carry out its functions efficiently and effectively (Kastis, 2007).

The techniques of cameras in the educational system is one of the techniques and modern tools that enable the organization to perform its various functions effectively. It is a modern technical system that has been used to develop work in many organizations. Many studies, such as the study of Al - Qahtani (2008) and the study of Al - Humaidani (2012) have proven the effective role of camera technology in managing various organizations. Hence, modern technologies in general in the field of education have an important role in improving educational processes, academic achievement, behavior modification and early intervention, as well as their role in saving effort, time and money.

Hence the need for a permanent and continuous review of what educational institutions offer, in order to introduce all that is new and help them to keep abreast of their programs of rapid and 
successive changes in technology, in the needs of learners and the environment in which they live. The developing countries in general and the Arab countries in particular are facing a real challenge due to the accelerating technological development in computer and communication technologies. It must determine its future vision for the advancement of the educational process (Hamdan \& Al-Obaidi, 2007).

The electronic management project is like any other project or program in terms of its needs, as it needs to create an environment appropriate to the nature of its work, so that the individual can achieve his/ her goals. Al - Aghbari (2006) mentioned a number of requirements for implementing electronic management, the most important of which are: Solving the problems that exist in the real reality before moving to the electronic environment, emphasizing the importance of this requirement, the infrastructure as electronic management requires an appropriate level of infrastructure that includes a modern network of communications and information and an advanced infrastructure for wired and wireless communications that can be able to provide communication and information transfer between the administrative institutions themselves and with others.

$\mathrm{Al}$ - Kofahi (2005) pointed to a set of requirements for implementing electronic management, including: Establishing strategies and founding plans, providing the necessary infrastructure for electronic management, developing administrative organization, services and governmental transactions according to a gradual transformation, education and training for teachers, awareness and education for employees, issuing the necessary legislation, or amending existing legislation, updating and ensuring the security and protection of information in electronic management.

Rationale for the installation of surveillance cameras and their role in monitoring electronic management, including: A number of researchers referred to in Al - Bayan (2008) indicated the importance of installing cameras in classrooms for the following reasons: Following - up on what will be monitored on a daily basis during the full school day, control student violations and place the hand on the location of the defect and correct it. Through these cases, the students who are caught by the surveillance cameras are transferred to the social and psychological specialists to follow - up the reasons that led them to commit the wrong behaviors. These cameras also make the students feel that they are censored and therefore seek to correct their situation and not to do anything contrary to. In the end, the result to which schools will be given is the decline in violence and problems that were previously practiced.

Electronic administrative control is one of the modern administrative means, the most important of which is in monitoring and reassuring the safety of the school environment. It relies on technical tools and works in conjunction with first - hand and real - time implementation. The information recorded immediately and is at the decision - maker. It is considered as one of the successful means of censorship because it relies on direct observation. It is conducted through advice, guidance and counselling. It can also include rewarding and motivating hardworking and 
punishing the neglected in the performance of their duties. The surveillance system through cameras works to: monitor student behaviors, monitor general performance at school, reduce negative behaviors of some students, and preserving school property form tampering and damaging, keeping the school day quiet among students, limiting thefts that happen from time to time, controlling the phenomenon of tampering with the walls, the breaking of cars, maintaining the security of the school, the safety of its members, knowing the most prevalent behaviors in the school and setting controls and solutions to address them (Mustafa, 2012).

\section{The goals of the electronic surveillance system:}

The electronic surveillance system aims at achieving the following:

1. Providing the administration with accurate and integrated information about all activities and their locations.

2. Real pictures transfer about activities, sites and events.

3. Providing information early on for problems and their areas to take appropriate decisions regarding them.

4. Evaluating the performance results directly and indicate the unacceptable performance and what it entails.

\section{Characteristics of electronic surveillance system:}

The following are from the characteristics of electronic surveillance system:

1. A database containing information about the school's performance and activities.

2. Achieving financial savings against high - quality and accurate results.

3. Recording events and activities around the clock and all facilities.

4. Identifying events and electronic alert to them without the intervention of people.

5. Working very efficiently.

6. Inclusivity in coverage in the short and long term.

The following is a presentation of some previous relevant studies that have been accessed, arranged from oldest to newest, according to their chronology. Altun (2004) conducted a study on the use of information technology in the classroom and explained the role of principals of elementary schools (smart experience) in Turkey. It aimed to reveal the roles of elementary school principals toward information technology and the expected role of them. The sample consisted of (17) principals and (15) computer coordinators from the central coordination office. One of its most prominent results is that the integrated impact of technology in education is mainly based on the effectiveness of principals and their activity as they are leaders and they should be trained during service.

Anderson and Dexter (2005) carried out a study aimed at identifying the patterns of technology used in various educational administrative disciplines and what are the proposals for their development in schools in the United States of America. The study sample consisted of two probable and two purposeful samples, so the final result of the database became $(4,100)$ teachers, (800) technical supervisors and (867) principals from (1150) schools. The questionnaire was 
used as a tool for study. Among its most important results were the emphasis on using the internet in educational programs and e-mail by principals and teachers, and emphasizing the development of a clear concept of information technology and developing laws for technology by identifying the type of students that use it.

$\mathrm{Al}$ - Qahtani (2008) conducted a study aimed at finding out the role of modern technology in protecting the biological establishment in the city of Riyadh.The survey methodology was adopted. The number of the study sample reached (660) individuals. One of the most important results that the study showed, not to use modern technologies such as voice or fingerprint.The Lawanda (2009) study aimed at identifying the extent of school principals' use of administrative accountability in the US State of Alabama, and their conformity with the federal model for evaluating school principals. The study used the descriptive methodology. The study sample consisted of (420) principals. The (SCAPQ) measure was used to measure the degree of school principals' practice of managerial accountability principles. The results indicated that (59\%) of the study participants did not engage in any activities related to administrative accountability. The Duflo and Hanna (2010) study aimed at finding out the monitoring of teachers' work and to obtain a data for their arrival in the developing rural areas of India. The observation method was used to collect data, by using cameras. 120 schools were randomly selected, and one of the most important results was the absence rate (measurement using unannounced visits in both treatment and comparison schools, from 42 - on average - in comparison schools to $22 \%$ in treatment schools). This program had a positive effect on the educational achievement levels on the child a year after the start of the program.

Bell (2011) carried out a study aimed at analyzing school principals' perceptions of the impact of technology on their roles in schools. The qualitative methodology was used in this study. 310 principals in the Gulf of Mexico were interviewed. The results indicated that $(62.3 \%)$ of school principals see that there is a positive impact of the use of technology on their roles in their schools. Salama (2013) conducted a study aimed at finding out the reality of monitoring and performance evaluation systems at the Islamic University in the Gaza Strip, to reveal the extent of the availability of the components of control systems and performance evaluation at the university and its role in achieving the goals, as well as its ability to reduce negative phenomena in it. The study sample consisted of (245) administrative employees. The questionnaire was used as a tool to collect data. The descriptive methodology was used. The results of the study concluded that the administrative control is applied in an efficient manner through which the objectives of the administrative control in the Islamic University of Gaza Strip are achieved. The results also indicated that performance evaluation is used as a monitoring tool in a correct and effective manner, which contributes to achieving the goals of administrative control systems at the university. The results indicated that the elements of communication and information are available, which achieves the goals of the administrative control systems at the university.

Abu Dalhom (2016) carried out a study aimed at finding out the level of control on schools by the educational capital region in the State of Kuwait, and its relation to job burnout among teachers, and the effect of sex, academic qualification, years of experience and school level 
Vol.8, Issue 2, pp.104-121, February 2020

Published by ECRTD- UK

Print ISSN: ISSN 2054-6351

Online ISSN: ISSN 2054-636X

variables. The sample of the study consisted of (56) male and female principals and (550) male and female teachers. The questionnaire was used to collect data. The results showed that there were no significant differences at $(\alpha \leq 0.05)$ attributed to sex, academic qualification, and years of experience and school level variables, in all fields related to control on schools by the educational capital region in the State of Kuwait, from school principals' point of view.

\section{Problem of the study}

Oversight is a scientific rationalization of the decisions taken by school administrators in the school administration course in full, starting with planning and ending with evaluation. It is the nerve that applies to aspects of school administrative work. The use of the camera technology, as a modern control tool, has led countries and organizations to make use of this technology in the administrative field, to follow up all State agencies. Accordingly, it is imperative to start modernizing and developing administrative control systems in the Kingdom of Saudi Arabia, and the adoption of camera technology as a tool to link school administrations with senior administration.

After the researcher met several officials in the Saudi Ministry of Education, he found that there was a plan to use an electronic surveillance system in all schools in the Kingdom, and preparations for this are ongoing. The fingerprint system has been introduced and work has begun on experimenting with the camera system. On the other hand, the researcher noted that school principals are among supporters and opponents of such a system, and this system has not been fully adopted without conducting scientific evaluation studies to the extent that school principals accept the expected surveillance system. This is what allows the researcher to carry out this study, whose it's problem is represented by the following main question: What is the proposed perception for developing a surveillance system by using the cameras technology on schools in the Kingdom of Saudi Arabia?

\section{Objective of the study and its questions:}

The study aimed at presenting a proposed perception for developing a surveillance system by using the camera technology on schools in the Kingdom of Saudi Arabia, by answering the following questions:

1. What are the obstacles to applying surveillance system by using the camera technology to schools in the Kingdom of Saudi Arabia?

2. What suggestions can be made to develop a surveillance system using camera technology in schools?

3. What is the degree of appropriateness of the suggestions for developing the surveillance system by using the camera technology for Saudi school administrations from the experts and specialists' point of view?

\section{Importance of the study}

The importance of the study lies in the importance of its subject, which includes determining the appropriate educational system to implement the project of camera technology. 
Vol.8, Issue 2, pp.104-121, February 2020

Published by ECRTD- UK

Print ISSN: ISSN 2054-6351

Online ISSN: ISSN 2054-636X

This study is the first of its kind - within the limits of the researcher's knowledge aimed at determining the degree to which school principals in the Kingdom of Saudi Arabia accept the system of monitoring their school administrations using cameras technology from their point of view. this study:

It is hoped that the following organizations and persons will benefit from the results of - Educational institutions that consider linking school administrations with higher departments as a strategic choice and a primary axis of the development of their educational project.

- Principals who seek technological development and who are interested in using this system and applying it in their schools, as it can be adopted as an important reference in that.

- $\quad$ The Ministry of Edcuation by employing the results of this study, and more specifically the decision makers in the ministry. This is among the steps taken to take appropriate decisions to implement this type of technology as an accredited system based on scientific foundations.

- Forming a societal information base to benefit from it in the future, whether by educational leaders or researchers in this field, as well as graduate students can benefit from in their research.

\section{Definition of terms:}

The study included some terms defined as follows:

Control: Al - Quthat (2008) provided a definition of control as the activity that the administration engages in the organization to make sure that the work is going in accordance with the policies and plans in place to achieve the goals of the organization and to detect deviations and work to fix them.

- $\quad$ Camera technology system: It is defined operationally for the purposes of this study that it is a technique consisting of a set of electronic imaging machines found in school administrations that take static or moving images within the school environment and work to transfer and store events related to a center for control and follow - up by the higher administrative levels in the administration.

Limitations: This study was limited to principals of secondary schools in the city of Riyadh in the Kingdom of Saudi Arabia during the first semester of the academic year 2017 / 2018.

\section{METHODOLOGY}

This part included a description of the study population, a sample distribution, a description of the study tool, its validity, reliability and application procedures, as well as a description of the statistical treatments used.

\section{Methodology of the study}

The study followed the descriptive survey methodology to suit it for the purposes of the study. 
Vol.8, Issue 2, pp.104-121, February 2020

Published by ECRTD- UK

Print ISSN: ISSN 2054-6351

Online ISSN: ISSN 2054-636X

\section{Population of the study}

The target study population consisted of all of the (1.186) school principals in the directorate of education for the Riyadh District, and of them (590) male principals made up (49.7\%) and (596) female principals constituted $(50.3 \%)$.

\section{The study sample}

The sample of the study consisted of (308) male and female principals, who were chosen by the stratified random sample method according to the sex variable, forming their percentage approximately (26\%) from the study population. Seven copies of the questionnaire were excluded because they were not valid for analysis, so that the sample consisted of (301) male and female principals. The sample made up $(25.4 \%)$ of the study population. The number of male principals in the study sample reached (153) principals, which constituted $(50.8 \%)$, while the female principals numbered (148) principals, which constituted $(49.2 \%)$ of the study sample.

\section{The study tool}

The researcher developed the study tool by reviewing the theoretical literature and previous studies on the subject of the study, such as the Abu Dalhoum (2016) study and Salama (2013) study. The tool was primarily composed of two parts: The first part dealt with the obstacles to applying surveillance system using the camera technology in schools. It consisted of (16) items, divided into two fields. The second part was an open question about the suggestions that could be made to develop a surveillance system using the camera technology in schools.

\section{Validity of the study tool}

The degree of validity of the tool was evaluated by presenting it to ten arbitrators who specialize in educational administration, educational technology and school principals. They were asked to express their views with the items of the study tool in terms of the suitability of the item in the field in which it was placed, and the clarity of the item, as well as the integrity and accuracy of the language and the ability to add or delete any item. Their opinions and amendments were taken into consideration. The items agreed upon by more than $(80 \%)$ arbitrators were retained. Three items were modified and no item was deleted. The final questionnaire consisted of (16) items distributed in two fields equally: the technical field (8) items and the human field (8) items.

\section{Reliability of the study tool}

The degree of reliability of the study tool was evaluated by test - retest method and the internal consistency method. The scale was applied and re-applied after two weeks to a group of principals outside the study sample consisting of (25) male and female principals. Table (1) shows the results. 
Vol.8, Issue 2, pp.104-121, February 2020

Published by ECRTD- UK

Print ISSN: ISSN 2054-6351

Online ISSN: ISSN 2054-636X

Table (1)

Reliability coefficients for the tool as a whole and for each field in a (test - retest) and internal consistency methods

\begin{tabular}{|l|l|l|}
\hline Field & Test - retest & Internal consistency Cronbach Alpha \\
\hline Technical & 0.89 & 0.75 \\
\hline Human & 0.86 & 0.79 \\
\hline Total & 0.91 & - \\
\hline
\end{tabular}

Table (1) shows that the study tool has acceptable degrees of reliability for the purposes of this study. The reliability coefficient for the tool as a whole, was (0.91) and for technical field was (0.89), while for the human field was (0.86). The reliability coefficient values for the two fields ranged from $(0.75-0.79)$.

\section{Statistical standard}

The Likert five - step scale was adopted to correct the study tool by giving each of its items one of its five grades (Very high, high, medium, low and very low) and represented digitally (5, 4, 3, $2,1)$ respectively. The following scale was adopted for the results analysis:

1. $\quad$ Less than or equal to $(2.33)=$ low degree.

2. $\quad$ Between $(2.34-3.67)=$ medium degree.

3. $\quad$ More than or equal to $(3.68)=$ high degree.

\section{RESULTS OF THE STUDY}

This part included a presentation of the results of the study that were reached by answering the study questions as follows:

Results related to the answer to the first question:

To answer this question: "What are the obstacles to applying surveillance system by using the camera technology to schools in the Kingdom of Saudi Arabia? Means and standard deviations are extracted. Table (2) shows that.

Table (2)

Means, standard deviations, ranks and the degree for the obstacles to applying the surveillance system by using the camera technology to schools in the Kingdom of Saudi Arabia as a whole and to the two fields are in descending order

\begin{tabular}{|l|l|l|l|l|}
\hline No. & Field & Mean & Standard deviation & Degree \\
\hline 1. & Technical & 4.21 & 0.84 & High \\
\hline 2. & Human & 3.95 & 0.93 & High \\
\hline \multicolumn{2}{l}{ Total score } & 4.08 & 0.83 & High \\
\hline
\end{tabular}

Table (2) shows that the mean of the obstacles as a whole was (4.08) with a standard deviation of (0.83) with a high degree. The technical field came first with a mean of (4.21) and a standard deviation of (0.84) with a high degree. As for the human field, it came in the second rank with a mean of (3.95) and a standard deviation of (0.93) with a high degree too. 
Vol.8, Issue 2, pp.104-121, February 2020

Published by ECRTD- UK

Print ISSN: ISSN 2054-6351

Online ISSN: ISSN 2054-636X

The following is a presentation of the items for each field:

The first field: technical:

Means and standard deviations were calculated for the estimates of the sample subjects for the items in this field. Table (3) shows the results.

Table (3)

Means, standard deviations, ranks and the degree for the items of technical field in descending order

\begin{tabular}{|l|l|l|l|l|l|}
\hline No. & Items & Mean & S.D. & Rank & Degree \\
\hline 8 & $\begin{array}{l}\text { Not allocating funds for their purchase and } \\
\text { securing special maintenance parts for them. }\end{array}$ & 4.59 & 0.85 & 1 & High \\
\hline
\end{tabular}

\begin{tabular}{|c|c|c|c|c|c|}
\hline No. & Items & Mean & S.D. & Rank & Degree \\
\hline 7 & The technical means need periodic maintenance. & 4.40 & 0.94 & 2 & High \\
\hline 6 & $\begin{array}{l}\text { The building is not equipped to use modern } \\
\text { technology. }\end{array}$ & 4.30 & 1.00 & 3 & High \\
\hline 5 & $\begin{array}{l}\text { Difficulty replacing the surveillance cameras } \\
\text { when they are intentional or unintended damage. }\end{array}$ & 4.15 & 1.04 & 4 & High \\
\hline 3 & Being damaged. & 4.15 & 1.06 & 4 & High \\
\hline 2 & $\begin{array}{l}\text { The possibility of a blackout leads to the } \\
\text { disabling of cameras and other devices. }\end{array}$ & 4.11 & 1.09 & 6 & High \\
\hline 4 & $\begin{array}{l}\text { Surveillance technologies from cameras are } \\
\text { affected by various weather factors, which } \\
\text { reduces their effectiveness. }\end{array}$ & 4.05 & 1.07 & 7 & High \\
\hline 1 & $\begin{array}{l}\text { The location of the cameras installation may not } \\
\text { help to provide good monitoring and control of } \\
\text { the whole place. }\end{array}$ & 3.97 & 1.08 & 8 & High \\
\hline \multicolumn{2}{|c|}{ Total scare } & 4.21 & 0.84 & - & High \\
\hline
\end{tabular}

Table (3) shows that the mean for the technical field was (4.21) and a standard deviation of (0.84) with a high degree. All items of this field came with a high degree. Their means ranged from (4.59 - 3.97). Item (8) that states "Not allocating funds for their purchase and securing special maintenance parts for them" came in the first rank. Its mean was (4.59) and a standard deviation of (0.85). While item (1) that states "The location of the cameras installation may not help to provide good monitoring and control of the whole place came in the final rank, with a mean of (3.97) and a standard deviation of (1.08).

This may be attributed to the fact that surveillance technology through cameras is a new technology that has been recently applied in some Saudi schools. The Ministry did not allocate to it many resources and financial credits, as it is in an experimental stage through which the 
Vol.8, Issue 2, pp.104-121, February 2020

Published by ECRTD- UK

Print ISSN: ISSN 2054-6351

Online ISSN: ISSN 2054-636X

Ministry tries to ensure the effectiveness of this technology in maintaining the security and safety of schools. In addition to that the use of any modern technology requires periodic maintenance and specialists in the field of technologies. Perhaps this result is attributed to the fact that this technology is still new, and that those dealing with it, do not have any previous experience using it, which may expose it to technical malfunctions. This result may also be attributed to the fact that these cameras were placed in places that were exposed to different weather conditions. As for the obstacle (1) that states "The location of the cameras installation may not help to provide good monitoring and control of the whole place "it got the last rank. This result may be attributed to the fact that the place of installing the cameras was based on the locations of the students' gatherings, without studying the students' reactions after installing them, which prompted students to avoid the where abouts of the cameras.

This result differed with the study of Salama (2013), which indicated that the elements of communication and information are available, in order to achieve the goals of administrative control in the Islamic University in the Gaza Strip.

\section{The second field: Human}

Means and standard deviations were calculated for the estimates of the study sample on the items of human field. Table (4) shows that.

Table (4)

Means, standard deviations, ranks and the degree for the items of human field in descending order

\begin{tabular}{|l|l|l|l|l|l|}
\hline No. & Items & Mean & S.D. & Rank & Degree \\
\hline 9 & $\begin{array}{l}\text { Individuals need training courses to use the } \\
\text { technology. }\end{array}$ & 4.22 & 0.99 & 1 & High \\
\hline 11 & $\begin{array}{l}\text { Camera workers resort to not checking in } \\
\text { to avoid embarrassment. }\end{array}$ & 4.04 & 1.08 & 2 & High \\
\hline 10 & $\begin{array}{l}\text { Fear of accountability in the event of the } \\
\text { disruption of the technical means used. }\end{array}$ & 4.04 & 1.15 & 2 & High \\
\hline 12 & $\begin{array}{l}\text { A sense of the importance of technology } \\
\text { by officials leads to a decrease in its } \\
\text { effectiveness. }\end{array}$ & 3.95 & 1.15 & 4 & High \\
\hline 15 & $\begin{array}{l}\text { Consider cameras as a kind of spying on } \\
\text { the work of the principal. }\end{array}$ & 3.90 & 1.21 & 5 & High \\
\hline 14 & $\begin{array}{l}\text { Consider cameras as a kind of insult and } \\
\text { distrust of the principal. }\end{array}$ & 3.84 & 1.21 & 6 & High \\
\hline 16 & $\begin{array}{l}\text { Considering the cameras a kind of } \\
\text { psychological pressure on the principal. }\end{array}$ & 3.83 & 1.21 & 7 & High \\
\hline 13 & $\begin{array}{l}\text { Principals' resistance to change. } \\
\text { Total score }\end{array}$ & 3.81 & 1.17 & 8 & High \\
\hline
\end{tabular}


Vol.8, Issue 2, pp.104-121, February 2020

Published by ECRTD- UK

Print ISSN: ISSN 2054-6351

Online ISSN: ISSN 2054-636X

Table (4) clarifies that the mean for the human field was (3.95) and a standard deviation of (0.93) with a high degree. The means of the items of this field ranged from $(4.22-3.81)$. Item (9) that states "Individuals need training courses to use the technology" came in the first rank. The mean was (4.22) and a standard deviation of (0.99) with a high degree. While item (13) that states "Principals' resistance to change" came in the last rank. Its mean was (3.81) and a standard deviation of (1.17).

This result may be attributed to the fact that the monitoring system using surveillance cameras needs to know how to use and maintain these technologies, which necessitates the participation of users of this technology, including principals and employees in training courses, to learn how to use and maintain modern technical means of the control system. It also may be attributed to the employees' fear of accountability in the event of any malfunction that may occur in the technical means used, which the ministry may refer to deliberately sabotaging by the employees to monitor. This is to prevent any malfunctions that may occur in the school that the principal may be exposed to accountability. As for the obstacle (13) which states "Principals' resistance to change", it got the last rank, and this result may be attributed to the fact that some school principals still believe in their ability to control their schools and maintain security in them, without the need for modern technologies that cause some external interference. They also trust the teachers' abilities to conduct the educational process without the need to monitor them with cameras, so that confidence between the teacher and the principal is not compromised. Also, the installation of surveillance cameras may reveal some aspects of the failure of school principals, thus some principals try to resist and reject them.

\section{RESULTS RELATED TO THE ANSWER TO THE SECOND QUESTION}

To answer the second question of the study: "What suggestions can be made to develop a surveillance system using camera technology in school?", the researcher performed the following procedures:

1. The open question in the study tool was answered by (109) male and female principals from the study sample whose number reached (301) male and female principals, which is (36\%) of the study sample.

2. All the suggestions mentioned in the answers of the study sample, which represent proposals for developing the monitoring system using the camera technology in the schools of the Kingdom of Saudi Arabia were monitored from male and female principals' point of view, which have been repeated five times and more. The researcher converted the respondents' answers to scientific suggestions, as shown in Table (5). 
Vol.8, Issue 2, pp.104-121, February 2020

Published by ECRTD- UK

Print ISSN: ISSN 2054-6351

Online ISSN: ISSN 2054-636X

Table (5)

Suggestions of male and female school principals as stated in the open question

\begin{tabular}{|c|c|c|c|}
\hline No & Suggestions & Frequency & Percentage \\
\hline 1 & $\begin{array}{l}\text { Choosing suitable places in schools to install cameras } \\
\text { based on an engineering and psychological study. }\end{array}$ & 41 & $37.6 \%$ \\
\hline 2 & $\begin{array}{l}\text { Cameras should be installed only on the external walls, } \\
\text { school grounds and public facilities, without classrooms } \\
\text { and laboratories. }\end{array}$ & 39 & $35.8 \%$ \\
\hline 3 & $\begin{array}{l}\text { Holding training courses for school principals and } \\
\text { workers on the camera surveillance system in schools. }\end{array}$ & 36 & $33 \%$ \\
\hline 4 & $\begin{array}{l}\text { Allocating staff working on a shift system to monitor } \\
\text { screens for the camera surveillance system in schools. }\end{array}$ & 31 & $28.4 \%$ \\
\hline 5 & $\begin{array}{l}\text { Allocating funds within the school budget to purchase } \\
\text { maintenance parts for the camera surveillance system in } \\
\text { schools. }\end{array}$ & 30 & $27.5 \%$ \\
\hline
\end{tabular}

\begin{tabular}{|l|l|l|l|}
\hline No & Suggestions & Frequency & Percentage \\
\hline 6 & $\begin{array}{l}\text { Preparing awareness leaflets showing the importance } \\
\text { and advantages of using the camera surveillance system } \\
\text { in schools and their positives. }\end{array}$ & 28 & $25.7 \%$ \\
\hline 7 & $\begin{array}{l}\text { Establishing instructional boards showing the presence } \\
\text { of surveillance cameras. }\end{array}$ & 27 & $24.8 \%$ \\
\hline 8 & $\begin{array}{l}\text { Optional manual registration. } \\
\text { Inclusion of the alarm feature in the event that the } \\
\text { camera surveillance system has been compromised in } \\
\text { schools. }\end{array}$ & 19 & $17.4 \%$ \\
\hline 10 & $\begin{array}{l}\text { Providing a technician specialized in reforming the } \\
\text { camera surveillance system in schools. }\end{array}$ & 15 & $11 \%$ \\
\hline 11 & $\begin{array}{l}\text { Enacting legal legislations that allow the use of the } \\
\text { camera surveillance system in schools, so that there is } \\
\text { no violation of the privacy of school employees and } \\
\text { visitors. }\end{array}$ & $\begin{array}{l}\text { Installing electric generators that work in the event of a } \\
\text { direct power outage, to ensure the continuity of the } \\
\text { camera surveillance system in schools. }\end{array}$ & 10 \\
\hline 13 & $\begin{array}{l}\text { Establishing a security system for the information } \\
\text { recorded on the camera surveillance system in schools. }\end{array}$ & 7 & $6.2 \%$ \\
\hline
\end{tabular}


Vol.8, Issue 2, pp.104-121, February 2020

Published by ECRTD- UK

Print ISSN: ISSN 2054-6351

Online ISSN: ISSN 2054-636X

\begin{tabular}{|l|l|l|l|}
\hline No & Suggestions & Frequency & Percentage \\
\hline 14 & $\begin{array}{l}\text { Providing a comprehensive insurance system for the } \\
\text { camera surveillance system to cover maintenance work } \\
\text { and replace damaged parts in the system. }\end{array}$ & $5.6 \%$ \\
\hline
\end{tabular}

Table (5) shows that the suggestion "Choosing suitable places in schools to install cameras based on an engineering and psychological study" obtained the highest response by the respondents who answered the open question with a percentage of $(37.6 \%)$. The suggestion "Cameras should be installed only on the external walls, school grounds and public facilities, without classrooms and laboratories" came in the second repetition with a percentage of $(35.8 \%)$. As for the suggestion "Providing a comprehensive system for the camera surveillance system to cover maintenance work and replace damaged parts in the system" had got the lowest percentage of $(4.6 \%)$.

The results showed that the suggestion "Choosing suitable places in schools to install cameras" was the most frequent. It was followed by the suggestion "to install cameras on the external walls and school grounds", and at the third rank came the suggestion holding training courses for school principals and workers on the camera surveillance system.

In the last rank came the suggestion to provide a comprehensive insurance system for the camera surveillance system and to replace the damaged parts in the system. This may be attributed to the agreement of the school principals on all the above suggestions due to their great importance in activating the camera surveillance system and overcoming the obstacles that face the system when applying it.

\section{Results related to the answer to the third question}

To answer this question: What is the degree of appropriateness of the suggestions for developing the surveillance system by using the camera technology for Saudi school administrations from the experts and specialists' point of view?

The researcher presented the suggestions for developing the surveillance system using the camera technology to a group of experts and specialists to express their opinion on the degree of suitability of the suggestions for developing the surveillance system using the camera technology for Saudi school administrations.

The suggestions that were reached by answering the second question shown in Table (5) are gradually presented to the quintent Likert to the degree of suitability and Table (6) shows these results. 
Vol.8, Issue 2, pp.104-121, February 2020

Published by ECRTD- UK

Print ISSN: ISSN 2054-6351

Online ISSN: ISSN 2054-636X

Table (6)

Means, standard deviations, ranks for the degree of suitability of the suggestions for developing the surveillance system using camera technology for Saudi school administrations from experts and specialists' point of view

\begin{tabular}{|l|l|l|l|l|l|}
\hline No. & Items & Mean & S.D. & Rank & Degree \\
\hline 11 & $\begin{array}{l}\text { Enacting legal legislations that allow the use of } \\
\text { the camera surveillance system in schools, so that } \\
\text { there is no violation of the privacy of school } \\
\text { employees and visitors. }\end{array}$ & 4.35 & 0.81 & 1 & High \\
\hline 7 & $\begin{array}{l}\text { Establishing instructional boards showing the } \\
\text { presence of surveillance cameras. }\end{array}$ & $\begin{array}{l}\text { Choosing suitable places in schools to install } \\
\text { cameras based on an engineering and } \\
\text { psychological study. } 4.05\end{array}$ & 1.36 & 3 & High \\
\hline
\end{tabular}

\begin{tabular}{|c|c|c|c|c|c|}
\hline No. & Items & Mean & S.D. & Rank & Degree \\
\hline 13 & $\begin{array}{l}\text { Establishing a security system for the information } \\
\text { recorded on the camera surveillance system in } \\
\text { schools. }\end{array}$ & 3.95 & 1.05 & 4 & High \\
\hline 3 & $\begin{array}{l}\text { Holding training courses for school principals } \\
\text { and workers on the camera surveillance system in } \\
\text { schools. }\end{array}$ & 3.95 & 1.05 & 4 & High \\
\hline 6 & $\begin{array}{l}\text { Preparing awareness leaflets showing the } \\
\text { importance and advantages of using the camera } \\
\text { surveillance system in schools and their } \\
\text { positives. }\end{array}$ & 3.95 & 1.10 & 4 & High \\
\hline 2 & $\begin{array}{l}\text { Cameras should be installed only on the external } \\
\text { walls, school grounds and public facilities, } \\
\text { without classrooms and laboratories. }\end{array}$ & 3.95 & 1.36 & 4 & High \\
\hline 9 & $\begin{array}{l}\text { Inclusion of the alarm feature in the event that } \\
\text { the camera surveillance system has been } \\
\text { compromised in schools. }\end{array}$ & 3.90 & 1.12 & 8 & High \\
\hline 4 & $\begin{array}{l}\text { Allocating staff working on a shift system to } \\
\text { monitor screens for the camera surveillance } \\
\text { system in schools. }\end{array}$ & 3.90 & 1.21 & 8 & High \\
\hline 8 & Optional manual registration. & 3.80 & 1.24 & 10 & High \\
\hline 12 & $\begin{array}{l}\text { Installing electric generators that work in the } \\
\text { event of a direct power outage, to ensure the } \\
\text { continuity of the camera surveillance system in } \\
\text { schools. }\end{array}$ & 3.70 & 1.26 & 11 & High \\
\hline
\end{tabular}


Vol.8, Issue 2, pp.104-121, February 2020

Published by ECRTD- UK

Print ISSN: ISSN 2054-6351

Online ISSN: ISSN 2054-636X

\begin{tabular}{|l|l|l|l|l|l|l|}
\hline No. & Items & Mean & S.D. & Rank & Degree \\
\hline 5 & $\begin{array}{l}\text { Allocating funds within the school budget to } \\
\text { purchase maintenance parts for the camera } \\
\text { surveillance system in schools. }\end{array}$ & 3.60 & 1.23 & 12 & Medium \\
\hline 10 & $\begin{array}{l}\text { Providing a technician specialized in reforming } \\
\text { the camera surveillance system in schools. }\end{array}$ & $\begin{array}{l}\text { Providing a comprehensive insurance system for } \\
\text { the camera surveillance system to cover } \\
\text { maintenance work and replace damaged parts in } \\
\text { the system. }\end{array}$ & 2.50 & 1.15 & 14 & Medium \\
\hline
\end{tabular}

Table (6) shows that suggestion (11) that states "Enacting legal legislations that allow the use of the camera surveillance system in schools, so that there is no violation of the privacy of school employees and visitors" obtained the first rank with a mean of (4.35) and a standard deviation of (0.81) and a high degree. In the second rank came the suggestion (7) that states "Establishing instructional boards showing the presence of surveillance cameras". Its mean was (4.15) and a standard deviation of (1.04) with a high degree. In the last rank came the suggestion (14), which states: "Providing a comprehensive insurance system for the camera surveillance system to cover maintenance work and replace damaged parts in the system" with a mean of (2.50) and a standard deviation of (1.15) with a medium degree.

This result may be attributed to the focus of experts and specialists on the legal and legislative aspect of using the system of surveillance with cameras technology for Saudi school administrations because of this great importance in organizing their work and preserving the rights of students and school employees on the one hand and preserving the rights of workers on the system and school administration on the other hand.

\section{Recommendations}

In light of the results of the study, the researcher recommended the following:

1. Holding special training courses using the technical means related to surveillance cameras and their maintenance methods, especially for female schools, in order to get rid of the fear of parents in female schools from the technique of monitoring cameras.

2. Adopting the solutions proposed in this study to address the obstacles that face the application of the school surveillance system using the camera technology.

3. The Ministry of Education enacts legislation and legal instructions to control the system of surveillance schools using cameras technology.

4. Providing the necessary financial resources to implement the surveillance system using the camera technology on schools in the Kingdom of Saudi Arabia and its maintenance.

5. Adopting the results of this study to be a guide for educational leaders in activating surveillance using the camera technology. 
British Journal of Education

Vol.8, Issue 2, pp.104-121, February 2020

Published by ECRTD- UK

Print ISSN: ISSN 2054-6351

Online ISSN: ISSN 2054-636X

\section{References}

Abu Dalhom, T.A. (2016). Control of schools by the capital educational district of the State of Kuwait and its relation to the career burnout of teachers (Unpublished Master Thesis). Al al bayt University, Al - Mafraq, Jordan.

Al - Aghbari, A. (2006). School administration: The contemporary planning and organizational dimension, $1^{\text {st }}$ ed., Beirut: Arab Renaissance House.

Al - Bayan (2008). Website, Retrieved from the link http://www.albayan.ae/our-homes/2008-1226-1.822551.

Al - Humaidani, F. (2012). The role of electronic surveillance systems in controlling borders in the Kingdom of Saudi Arabia (Unpublished Master Thesis). Naif Arab University for Security Sciences, Riyadh, Kingdom of Saudi Arabia.

$\mathrm{Al}$ - Kofahi, M. (2005). Administrative control and its impact on the effective job performance of employees in education directorates in Jordan (Unpublished Ph.D. Dissertation), Yarmouk University, Irbid, Jordan.

Al - Qahtani, H. (2008). The role of modern technology in protecting vital installations (Unpublished Master Thesis), Naif Arab University for Security Sciences, Riyadh, Kingdom of Saudi Arabia.

$\mathrm{Al}$ - Quthat, H. (2008). Administrative control and its relationship to performance efficiency: An applied study on employees in the Jordanian Ministry of Health, The Arab Journal of Management, (Jordan), 28(2), 111-146.

Al - Saidi, S. (2007). Education engineering and smart schools (Scenarios and application mechanisms), Alexandria: Modern University Office.

Altun, S. (2004). "Information technology classrooms and elementary school principals' roles: Turkish experience", Education \& Information Technology, 9(3), 255-270.

Anderson, R. \& Dexter, S. (2005). School technology leadership: An empirical investigation of prevalence and effect, Educational Administration Quarterly, 40(1), 49-82.

Bell, R. (2011). An analysis of principals' perceptions of technology's influence in today's schools, (Unpublished Doctoral Dissertation), University of Houston, USA.

Duflo, E. \& Hanna, R. (2010). Monitoring works: Getting teachers to come to school. NBER Working paper, No. 11880.

Hamdan, M. \& Al - Obaidi, S. (2007). "E-learning: Concept, features, and examples from international and Arab experiences". Arab Network series of open education and distance education, Amman, Jordan.

Kastis, N. (2007). Observing the e-learning phenomenon: The case of school education, Paper, No. (4).

Lawanda, E. (2009). Accountability practices of school counsellors (Unpublished Master Thesis). Auburn University, Alabama, USA. Available on: http://hdi.handle.net/10415/1715.

Mustafa, M. (2012). Administrative control, $1^{\text {st }}$ ed. Amman: Dar Bedaya, Publishers and Distributors. 
British Journal of Education

Vol.8, Issue 2, pp.104-121, February 2020

Published by ECRTD- UK

Print ISSN: ISSN 2054-6351

Online ISSN: ISSN 2054-636X

Nyagowa, H., Ocholla, D. \& Mutual, S. (2011). Construction and validation of school success model, Proceedings of the European Conference on Information Management, 2011, p. 572.

Race, P. (2005). 500 tips for open and flexible e-learning. London: Kogan Page Limited.

Salama, A. (2013). Evaluation of monitoring systems and performance evaluation at the Islamic University in the Gaza Strip, Supplementary research, Suez Canal University, Egypt. 